\title{
FEMINIST FORESIGHT IN STATELESSNESS: CENTURY-OLD CITIZENSHIP EQUALITY CAMPAIGNS
}

\author{
DEIRDRE BRENNAN*
}

It may have appeared to many working in the statelessness sector, or those campaigning against gender discriminatory nationality laws, that until the launch of the Global Campaign for Equal Nationality Rights in 2014, efforts to eradicate such laws were largely only coordinated on a national level. This article, however, uncovers a hidden period in statelessness history: the citizenship equality campaigns of the early 1900s. Through an exploration of these campaigns, their vibrant tactics and eccentric characters, this article provides a feminist revisionist history of statelessness activism and academia that aims to adjust dominant narratives in contemporary statelessness literature.

\section{TABLE OF CONTENTS}

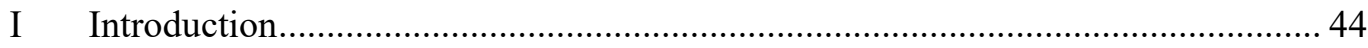

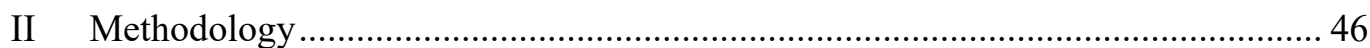

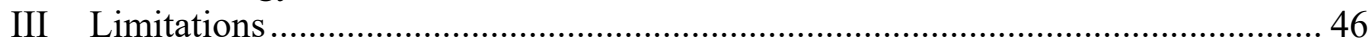

IV Part 1: Feminist Revisionist History - 1900s Campaigning................................... 46

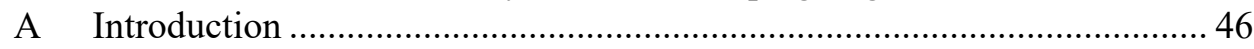

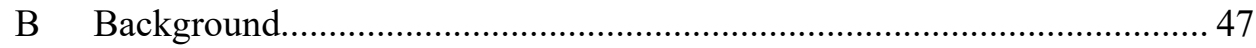

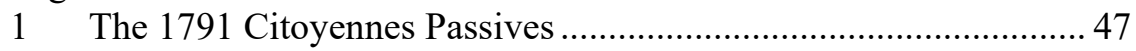

2 Nineteenth Century Beginnings .................................................... 48

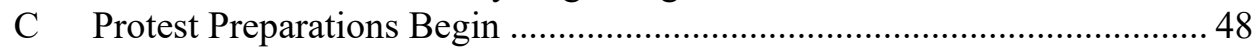

D Conflict at the Peace Palace........................................................................ 50

E The Convention on Certain Questions Relating to the Conflict of Nationality Laws 1930............................................................................. 51

F The Convention on the Nationality of Women 1933 ...................................54

G The Ferocity of the Feminist Cause..........................................................5

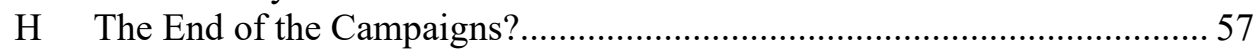

V Part 2: Decentring Statelessness History — A Discussion ......................................5 57

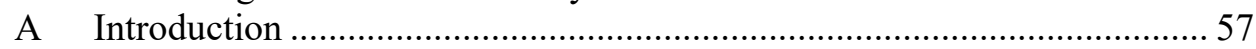

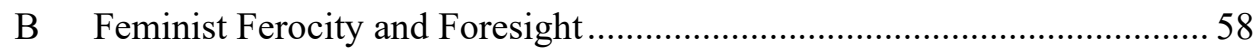

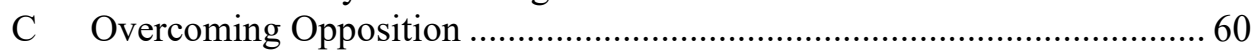

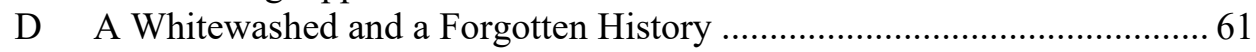

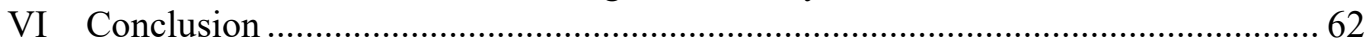

* PhD Candidate, Peter McMullin Centre on Statelessness. This article would have neither started, nor finished, without Zahra Albarazi's words of encouragement and knowledgeable advice. My thanks to Zahra for the generosity of her time in discussing all things Citizenship Equality Campaigning, in the month-long writing retreat she unintentionally signed up for, in Melbourne, in early 2020. The language and format of the article have benefited enormously from my father, Michael Brennan, another unwitting accomplice thanks to the forces of a lockdown. I am also extremely grateful to the two anonymous peer reviewers who volunteered their time to provide thorough and considered feedback. Finally, my thanks to my supervisors Susan Kneebone, Michelle Foster and Ana Dragojlovic, for their support and advice throughout the writing of this article. 


\section{INTRODUCTION}

On 13 March 1930, feminist activists from around the world descended on The Hague to protest a gathering of the League of Nations. Not invited to the opening ceremonies of the conference, the activists held a protest rally a few doors away. Gaining plenty of attention by the press, they were dressed colourfully, using their clothes to represent the countries they came from and the restricted women's rights that existed there. White clothes stood for complete equality, while pink and blue etc signified a change in law toward equality. Black, worn by the hosting Dutch feminists, meant complete discrimination in the law. While this lively event sounds like the actions of suffragettes of that period, the discriminatory laws these women were protesting were in fact nationality laws. In 1930, nationality laws in all but five countries in the world made distinctions based on sex, specifically discriminating against women by making their nationality dependent on that of their husbands. ${ }^{1}$ In 2020 , there remains roughly 50 countries in the world that continue to discriminate against women in regard to their nationality. ${ }^{2}$

The launch of the Global Campaign for Equal Nationality Rights in 2014, to work toward the full eradication of gender discriminatory nationality laws ('GDNL') was very welcome, particularly to those working on ending statelessness. ${ }^{3}$ Statelessness is a real consequence of GDNL for millions of children born to mothers in those 25 countries where women do not have the same right as men to pass on their nationality. ${ }^{4}$ However, what this article reveals possibly for the first time to many working on statelessness today - is that women's citizenship equality campaigns are not new. So highly regarded, and prominent, was the importance of women's nationality rights during the early 1900 s, that the newly formed International Woman Suffrage Alliance was renamed the International Alliance of Women for Suffrage and Equal Citizenship (the 'Alliance'). ${ }^{5}$ Also, in notable similarity to today's Global Campaign for Equal Nationality Rights, the protests of the 1930s have been referred to as 'the campaign for equal nationality rights'. ${ }^{6}$ Once pulled, this thread of early twentieth century GDNL campaigning reveals an abundance of literature written on these

1 The five countries were Argentina, Chile, Paraguay, Uruguay and the Soviet Union: see Candice Lewis Bredbenner, A Nationality of Her Own: Women, Marriage, and the Law of Citizenship (University of California Press 1998) 195 n 1.

2 For a full list of the countries and other information relating to gender discriminatory nationality laws: see 'The Problem', Global Campaign for Equal Nationality Rights (Web Page) $<$ https://equalnationalityrights.org/the-issue/the-problem $>$ ('The Problem').

3 As will be detailed later, there have been several variations of gender discriminatory nationality laws ('GDNL') over the past century, some have been almost fully eradicated, and others not. In this article, GDNL is used as an umbrella term for each form of nationality law that discriminates against women.

4 Cf Lina Abou-Habib, 'Gender, Citizenship, and Nationality in the Arab Region' (2003) 11(3) Gender and Development 66, 67; Zahra Albarazi, 'No Legal Bond, No Family Life' (2014) 19(1-2) Tilburg Law Review 11, 12; Zahra Albarazi, Deirdre Brennan and Laura van Waas, 'Gender Discrimination in Nationality Laws: Human Rights Pathways to Gender Neutrality' in Niamh Reilly (ed), International Human Rights of Women (Springer 2019) 193, 196.

5 Bredbenner (n 1) 203.

6 Carol Miller, "Geneva - the Key to Equality": Inter-War Feminists and the League of Nations' (1994) 3(2) Women's History Review 219, 226. 
campaigns. ${ }^{7}$ That literature conveys the vibrancy of the campaigns - the characters, the conversations and disagreements between them, misogynistic slurs against them, the parades and protests staged, and the drafting of documents and conventions by feminist lawyers and academics - although the present article does not deal with these in detail.

Instead, this article details, in the first Part, key historical events in the citizenship equality campaigns of the early part of the twentieth century. The aim is to firmly insert these milestone events in statelessness history, thereby adjusting the dominant impressions found in contemporary statelessness studies that international attention, or action, on statelessness emerged as a result of the First World War, ${ }^{8}$ that the 'heyday' was in the $1950 \mathrm{~s},{ }^{9}$ and that there has been an 'unprecedented surge' in interest in statelessness since $2010 .{ }^{10}$ Indeed, the discovery of literature on early twentieth century campaigns is corrective to the author's knowledge of the history of eradicating GDNL. ${ }^{11}$ The second part of this article discusses the significance of the early 1900 s citizenship equality campaigns for contemporary statelessness academia and action, both as a source of inspiration

7 Chrystal Macmillan, 'Nationality of Married Women: Present Tendencies' (1925) 7(4) Journal of Comparative Legislation and International Law 142; Bertha Lutz, 'Nationality of Married Women in the American Republics' (1926) 60(4) Bulletin of the Pan American Union 392; Muna Lee, 'The Inter-American Commission of Women: A New International Venture' in A Pan-American Life: Selected Poetry and Prose of Muna Lee (Jonathan Cohen ed, University of Wisconsin Press 2004) 222, originally published in Pan-American Magazine (October 1929); Blanche Crozier, 'The Changing Basis of Women's Nationality' (1934) 14(1) Boston University Law Review 129; Jacqueline Bhabha and Sue Shutter, Worlds Apart: Women under Immigration and Nationality Law (Longwood 1985); Miller (n 6); Mary Trigg, “"To Work Together for Ends Larger than Self": The Feminist Struggles of Mary Beard and Doris Stevens in the 1930s' (1995) 7(2) Journal of Women's History 52; Bredbenner (n 1); Nitza Berkovitch and Nișșā Berqôvîč, From Motherhood to Citizenship: Women's Rights and International Organizations (John Hopkins University Press 1999); Ellen C DuBois, 'Internationalizing Married Women's Nationality: The Hague Campaign of 1930' in Karen Offen (ed), Globalizing Feminisms, 1789-1945 (Routledge 2010) 204; Katarina Leppänen, 'The Conflicting Interests of Women's Organizations and the League of Nations on the Question of Married Women's Nationality in the 1930s' (2009) 17(4) Nordic Journal of Feminist and Gender Research 240; Karen Knop and Christine Chinkin, 'Remembering Chrystal Macmillan: Women's Equality and Nationality in International Law' (2001) 22(4) Michigan Journal of International Law 523; Mary E Daly, 'Wives, Mothers, and Citizens: The Treatment of Women in the 1935 Nationality and Citizenship Act' (2003) 38(3-4) ÉireIreland 244; Feryal M Cherif, Myths about Women's Rights: How, Where, and Why Rights Advance (Oxford University Press 2015); Helen Irving, Citizenship, Alienage and the Modern Constitutional State: A Gendered History (Cambridge University Press 2016); Linda Guerry, 'Married Women's Nationality in the International Context: 1918-1935', tr Ethan Rundell [2016] (43) Clio. Women, Gender, History 73; Paolo Amorosa, 'Pioneering International Women's Rights? The US National Woman's Party and the 1933 Montevideo Equal Rights Treaties' (2019) 30(2) European Journal of International Law 415.

8 Cf Laura van Waas, Nationality Matters: Statelessness under International Law (Intersentia 2008) 93; Kristy A Belton, 'Ending Statelessness through Belonging: A Transformative Agenda?' (2016) 30(4) Ethics and International Affairs 419, 420; Karen Knop, 'Relational Nationality: On Gender and Nationality in International Law' in T Alexander Aleinikoff and Douglas Klusmeyer (eds), Citizenship Today: Global Perspectives and Practices (Carnegie Endowment for International Peace 2001) 89, 96; Berkovitch and Berqôvîč (n 7) 80.

9 Miriam Rürup, 'Lives in Limbo: Statelessness after Two World Wars' (2011) 49(Fall) Bulletin of the German Historical Institute 113, 130. Cf Lindsey N Kingston, "AA Forgotten Human Rights Crisis": Statelessness and Issue (Non)Emergence' (2013) 14(2) Human Rights Review 73, 75.

10 Laura van Waas, “"Are We There Yet?” The Emergence of Statelessness on the International Human Rights Agenda' (2014) 32(4) Netherlands Quarterly of Human Rights 342.

11 Albarazi, Brennan and van Waas (n 4) 197-98. 
and as a possible influence on current deliberations about how to 'end statelessness'. 12

\section{METHODOLOGY}

The historical narrative relies principally on secondary sources for accounts of citizenship equality campaigns during the interwar period. Work particularly by Ellen DuBois brings to life much of the colourful interactions of feminists and their protagonists during a month-long conference on nationality in The Hague. The work of Caroline Bredbenner is called on for her detailed descriptions of the United States' feminist movement against unequal citizenship laws. And, Mary Daly's rich account of the young Irish state's position on GDNL in the 1920s and '30s is the background to a case example here.

A small number of primary sources from the early 1900s are analysed within this article. Feminist campaigners for equal citizenship in the early 1900s were often lawyers or academics, and so their own arguments and thoughts on the issue are important to modern scholars approaching the issue from a legal or theoretical viewpoint. From that period, writings by US poet and activist Muna Lee are referenced, as well as work by Scottish suffragette and barrister Chrystal Macmillan and prominent Brazilian suffragette Bertha Lutz. A small number of original texts by lawyers and politicians in opposition to the demands of the citizenship equality campaigners are also analysed.

\section{LIMITATIONS}

This article's heavy reliance on secondary sources has limited the focus to citizenship equality campaigns in the Western context in the early 1900s. Little is known, or at least written about in English - another limitation of this study of similar activism in other regions during that period.

\section{PART 1: FEMINIST REVISIONIST HISTORY - 1900s CAMPAIGNING}

Few international questions present such conflicting and perplexing aspects as that of the nationality of women. It is a modern question ... Now [women] have been forced into a rude awareness of the completely chaotic conditions of existing nationality laws. ${ }^{13}$

Muna Lee, 1929

\section{A Introduction}

At the time of the First World War, nationality laws implied that a woman was compulsorily stripped of her nationality upon marriage to a foreign man. ${ }^{14}$ In contradiction to the idea that the First World War brought women's nationality issues to the forefront, Chrystal Macmillan, in 1925, reminded readers that the International Council of Women (the 'International Council') first took up the

12 Cf 'Ending Statelessness', United Nations High Commissioner for Refugees (Web Page) $<$ https://www.unhcr.org/en-ie/ending-statelessness.html>.

13 Lee (n 7) 222.

14 Macmillan (n 7) 154. 
issue in $1905 .{ }^{15}$ Nevertheless, as this article is largely reliant on secondary sources to recount early twentieth century activism - the majority of which focus on the interwar period - the 1920s and '30s are the main period of attention. Before detailing highlights of those campaigns, it is instructive to look at a brief history of the origins of 'nationality', and the simultaneous growth of feminist activism throughout the eighteenth and nineteenth centuries.

\section{B Background}

\section{The 1791 Citoyennes Passives}

The concept of 'nationality' and its codification began over a hundred years prior to the citizenship equality campaigns of the early twentieth century. ${ }^{16}$ This historical account begins in France, the first modern nation to codify nationality. ${ }^{17}$

In the wake of the dissolution of the feudal system in France in 1789, revolutionaries claimed to represent universal principles and combat class oppression. ${ }^{18}$ However, this articulation of freedom and equality was noted by feminists of the era as completely oblivious to women's subordination. ${ }^{19}$ A 1791 manifesto of feminist claims, by Olympe de Gouges, was a most radical critique of the new nation. ${ }^{20}$ Her fight was against the exclusion of women from equal enjoyment of liberty and equality on the grounds that women 'naturally' belonged to the family. ${ }^{21}$ Women's subordination and exclusion was in fact written into France's 1791 constitution, defining women as citoyennes passives. ${ }^{22}$ Citizenship in the constitution was status-driven, and women, as 'passive citizens', did not possess full political rights. ${ }^{23}$ The majority of men, on the other hand, were defined as 'active citizens'. ${ }^{24}$ Women were joined in their passive category by children, servants and a 'motley assortment of civic outsiders'. ${ }^{25}$ Unlike most of the 'marginal comrades', Annie Smart points out that women were born 'passive' and remained so, without any opportunity to grow up or out of their category. ${ }^{26} \mathrm{In}$ 1793, de Gouges was rewarded for her 'vehement feminist attacks' on revolutionaries with death by guillotine, and subsequently all women's clubs were declared illegal. ${ }^{27}$ De Gouges had been specifically campaigning for the civil and political rights associated with citizenship — as opposed to citizenship as a legal status. Had she lived another decade, however, she would have witnessed (and likely campaigned against) the 1804 Napoleonic Code, which made a woman's

15 ibid 143.

16 In conformity with statelessness academia, nationality and citizenship are used interchangeably to denote the legal tie between a person and the state.

17 Verena Stolcke, 'The "Nature" of Nationality' in Veit Bader (ed), Citizenship and Exclusion (Palgrave Macmillan 1997) 61, 66.

18 ibid 67.

19 ibid.

20 ibid.

21 ibid.

22 La Constitution du 3 septembre 1791 [French Constitution of 3 September 1791]. See also Annie K Smart, Citoyennes: Women and the Ideal of Citizenship in Eighteenth-Century France (University of Delaware Press 2011) 134.

27 Stolcke (n 17) 67. 
citizenship dependent on that of her husband. ${ }^{28}$ The principle of jus sanguinis, the inheritance of citizenship through fathers explicitly, was deemed fundamental to warranting loyalty at a time when the Napoleonic wars encompassed Europe. ${ }^{29}$

\section{$2 \quad$ Nineteenth Century Beginnings}

There was, in the nineteenth century and only in certain countries, a growing but gradual momentum in advocacy movements for women's rights. Starting with the seminal 1848 Seneca Falls Convention in New York, US activists promoted the idea of such women's rights conventions at which a wide spectrum of women's grievances could be expressed and affirmed. ${ }^{30}$ High on the women's agenda from the outset was the extension of full franchise to women. Pragmatic demands were also prominent, the right to education and payment for work done, while the position of the married woman was singled out by campaigners and declared to be that of the 'civilly dead'. ${ }^{31}$ In 1888 in Washington DC, at a meeting attended by 53 women's organisations from nine countries, the US National Women's Suffrage Association helped to found a new organisation, the International Council. ${ }^{32}$ By 1905 the International Council had grown to having national branches in 35 countries. ${ }^{33}$ In that same year, the International Council carried out 'a special investigation' on the issue on unequal nationality laws and continued advocating for reform in the decades that followed. ${ }^{34}$

\section{Protest Preparations Begin}

The interwar years saw the growth of a global citizenship equality campaign. Several national feminist organisations petitioned their respective governments on the issue, and local commitment translated to wider united action on the issue. Globally, the Alliance became committed to the principle that 'married women should enjoy all the freedom granted to men to retain or alter their nationality'. ${ }^{35}$ In 1923 the Alliance put together a set of international guidelines as, in the words of Caroline Bredbenner, a 'cure for the dismal state of married women's nationality rights'. ${ }^{36}$ The collaborative nature of international activism is clear from the Alliance's response to the 1928 announcement that the League of Nations would hold a Conference on Codification of International Law in 1930, in The

8 ibid 66.

29 ibid.

30 Gerda Lerner, 'The Meaning of Seneca Falls: 1848-1998' (Fall 1998) Dissent 35-36.

31 The damning conclusion of 'civilly dead' would have full resonance in the nineteenth and early twentieth centuries when the legislation passed by national governments invariably excluded the mother's right to pass on nationality to her children: see 'Declaration of Sentiments' in Report of the Woman's Rights Convention Held at Seneca Falls (John Dick 1848) 7.

32 Linda L Clark, Women and Achievement in Nineteenth-Century Europe (Cambridge University Press 2008) 251.

33 Macmillan (n 7) 143.

34 ibid.

35 Bredbenner (n 1) 198.

36 ibid. 
Hague (the 'Hague Conference'). ${ }^{37}$ When the announcement was made, a committee created by the Alliance sprang into action. The committee was directed by three pioneering lawyers, Chrystal Macmillan, France's Maria Vérone and Betsy Bakker-Nort from the Netherlands. ${ }^{38}$

At the same time, and since the formation of the Inter-American Commission of Women ('IACW') in 1928, ${ }^{39}$ significant efforts to secure equal nationality rights for women at the Hague Conference were being made by US feminists. Alice Paul, described as a leading figure in the US feminist community, spent two years collating a volume of work on nationality laws around the world. Laws were sent to Paul and her colleague Dorothy Stevens, in their original text and with translations, from feminists in 84 countries. Languages included Japanese, Greek, Siamese, Bulgarian and Russian. ${ }^{40}$ The IACW, led by Paul, put together another progressive text, the Equal Nationality Treaty, which was registered by the Council of the American Institute of International Law. The Treaty stated that a contracting party shall make "no distinction based on sex in their laws and practice relating to nationality'. ${ }^{41}$ The Treaty specifically guaranteed the right of mothers, equally with fathers, to transmit nationality to their children. ${ }^{42}$ For women in the US, the next step was getting to the Hague Conference. At this point in the feminist history of statelessness, Manley O Hudson makes his appearance. In modern statelessness literature, Hudson is known for his prominent role in writing the definition of a stateless person in the 1950s. ${ }^{43}$ In 1930, however, Hudson was a technical adviser to the US delegation to the Hague Conference, the delegation on which feminist activists were fiercely trying to secure representation. Hudson was clear that he did not want women to be officially part of the delegation. ${ }^{44} \mathrm{On}$ failing to secure delegatory positions, national feminist organisations sent their own, unofficial, delegates to The Hague. ${ }^{45}$

37 Conflicts and differences of tactics did, however, exist across groups and so this collaboration should not be oversimplified nor romanticised: see Miller (n 6) 229; Trigg (n 7) 61; Bredbenner (n 1) 216. In literature on the Inter-American Commission of Women ('IACW'), attention is largely placed on the contributions of North American activists. Dorothy Stevens and Alice Paul are particularly noted as key leaders in the Pan-American alliance. On closer examination, however, it is possible to find reference to a strain between Latin and Northern American feminists. Latin American members were resentful of a perceived hijacking of the IACW by Dorothy Stevens. Limited by the availability of literature available, the present article does not illustrate the extent to which women of colour were ignored, or muted, as a means for white women's emancipation in the early 1900s: see Ann Towns, 'The InterAmerican Commission of Women and Women's Suffrage, 1920-1945' (2010) 42(4) Journal of Latin American Studies 779, 796. See also Katherine M Marino, Feminism for the Americas: The Making of an International Human Rights Movement (University of North Carolina Press 2019) 74.

38 DuBois (n 7) 206.

39 In Spanish: Comisión Interamericana de Mujeres ('CIM').

40 Lee (n 7) 223. See generally Amorosa (n 7).

41 Bredbenner (n 1) 204.

42 ibid 236.

43 Guy Goodwin-Gill, 'Statelessness Is Back (Not That It Ever Went Away ...)', EJIL: Talk! (Blog Post, 12 September 2019) <https://www.ejiltalk.org/statelessness-is-back-not-that-itever-went-away/>.

44 Bredbenner (n 1) 206.

45 ibid 207. 


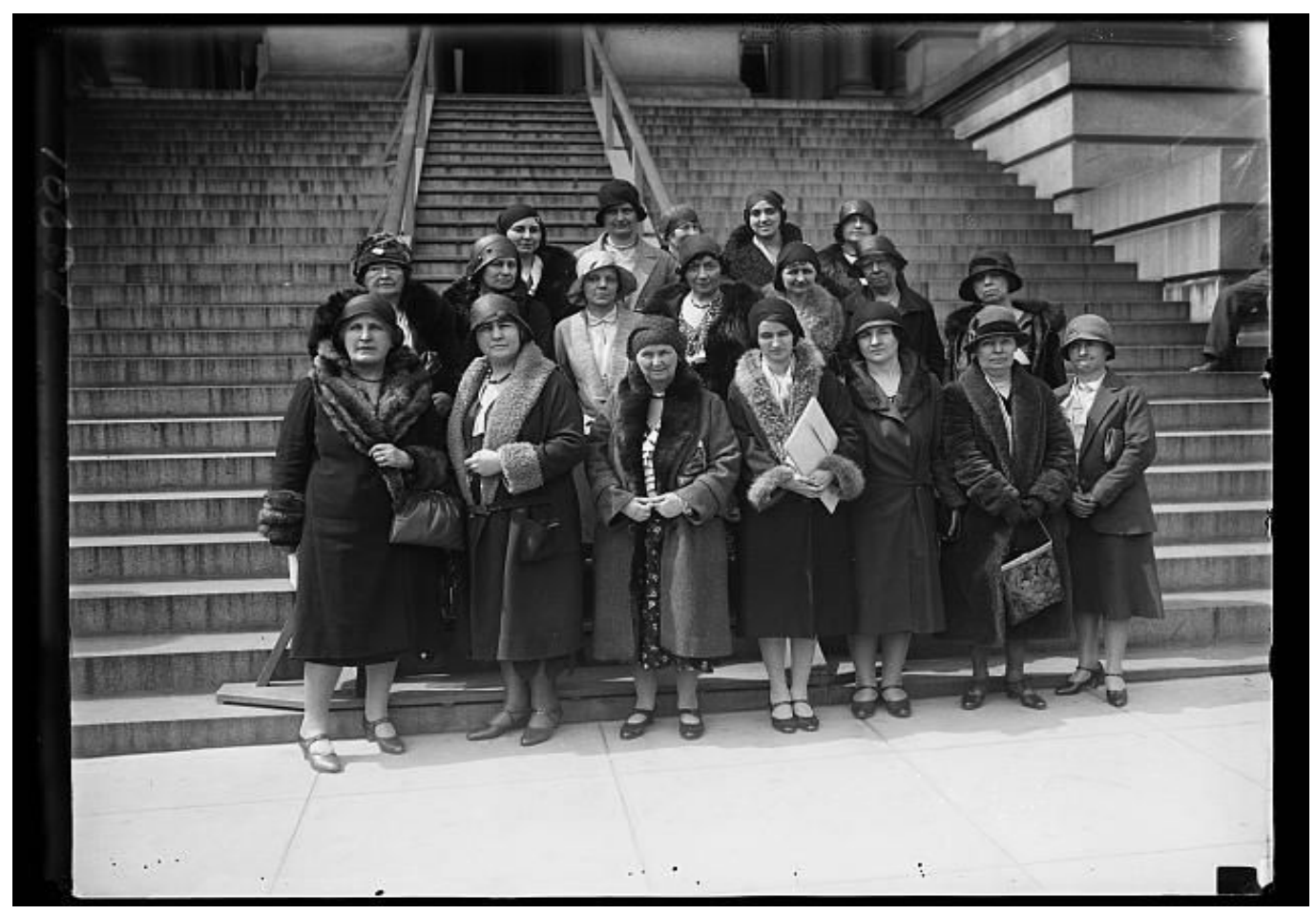

Image 1: National Association Women Lawyers petitioning US Plenipotentiaries to vote for equality at The Hague. Washington, 1930 (Harris \& Ewing Collection, Library of Congress Prints and Photographs Division). ${ }^{46}$

\section{Conflict at the Peace Palace}

'[T]he unattainable dream' 47

By opening night of the Hague Conference, 13 March 1930, women had arrived from around the world. As the formal opening ceremonies commenced, a women's protest procession took place nearby, a 'public spectacle adapted from the grand suffrage parades of the past'. ${ }^{48} 35$ countries were represented by the participants. ${ }^{49}$ Women from each nation carried their respective country's flag and their dress colour symbolised their country's nationality laws. According to Ellen DuBois, '[ $\mathrm{t}$ ] he closer to the [Alliance's] Committee on Nationality's proposed standard of independent nationality for wives, the more cheerful the colours'. ${ }^{50}$ The black colour of the Dutch dress, and the irony of the location of the protest, was not lost on the Dutch activist, Betsy Bakker-Nort. She observed that the 'legal situation of

\footnotetext{
46 'Prints \& Photographs Online Catalog', Library of Congress (Web Page) $<$ https://www.loc.gov/pictures/item/2016878749/>.

47 Quoted in newspapers describing women's proposal for equal nationality rights, Chairman of the Codification Conference and long-time enemy of the Dutch woman suffrage movement, former Prime Minister Theodorus Heemskerk: see DuBois (n 7) 207.

48 ibid 206.

49 Berkovitch and Berqôvîč (n 7) 81.

$50 \quad$ DuBois (n 7) 206.
} 
women [in the Netherlands] is still based on the obsolete principle of subjection of women to men'. 51

The momentum of the protesters did not wane throughout the month-long Hague Conference. Bredbenner and DuBois record exactly how the persistence of the protesters was received by the League of Nations delegates, noting how a joint memorandum sent to the Hague Conference by the International Council and the Alliance was read to the assembled delegates on 13 March. Representatives from the two women's groups were given permission to meet with the Bureau of the Hague Conference on the proviso that this would by no means affect the general Conference. ${ }^{52}$ At the meeting, the women emphasised their commitment to nationality-law reform for the next 25 years, and insisted that they be given an opportunity to speak before the full assembly on behalf of women, saying '[e]ven a criminal is not refused a legal defender'. ${ }^{33}$ Within two weeks, and following the arrival of the 'militant' American feminists, ${ }^{54}$ the actions of the women as unofficial delegates had finally antagonised the presiding officer of the Hague Conference. ${ }^{55}$ The presiding officer was Theodorus Heemskerk, ex-Prime Minister of the Netherlands and long-time enemy of the Dutch women's suffrage movement. ${ }^{56}$ Heemskerk claimed that the women's groups were harassing the delegates. He gave an order to the Dutch police to eject them from the grounds of the Peace Palace and he then had them barred. ${ }^{57}$ Not to be defeated, the women simply regrouped and resumed their protests outside the palace gates.

The tenaciousness of the protesters annoyed Heemskerk, who was quoted in the press angrily claiming that the women 'came not merely as strangers, but with the hostile intention of frustrating the work of the conference'. ${ }^{58} \mathrm{He}$ also referred to the feminists' proposals for equality as 'the unattainable dream'. 59 The Hague Conference was reportedly a rather dull international event in many respects, and so the actions of the feminists were pursued by news reporters who delighted in the 'publicity-seeking' activists. ${ }^{60}$

\section{E The Convention on Certain Questions Relating to the Conflict of}

\section{Nationality Laws 1930}

The only outcome agreed upon at the Hague Conference was the Convention on Certain Questions Relating to the Conflict of Nationality Laws (the 'Hague Convention'). ${ }^{61}$ In spite of the colourful and persistent campaigning of feminists at the Hague Conference, the Hague Convention was not to their satisfaction. It did not uphold equality between men and women in terms of nationality, but only addressed women's nationality rights insofar as ensuring that they would not become stateless (arts 8-11) or dual nationals. The Hague Convention still

51 ibid 207.

52 ibid.

53 Bredbenner (n 1) 210.

54 DuBois (n 7) 201.

55 Bredbenner (n 1) 210.

56 DuBois (n 7) 201.

57 Bredbenner (n 1) 210.

58 ibid 210-11.

59 DuBois (n 7) 207.

60 Bredbenner (n 1) 211.

61 Convention on Certain Questions Relating to the Conflict of Nationality Laws, opened for signature 12 April 1930, 179 LNTS 89 (entered into force 1 July 1937). 
retained the idea that married women's nationality was conditional. This, the campaigners understood, implied inferior. ${ }^{62}$ It is worth noting here that while campaigners prioritised equality, choice, autonomy and in particular the disestablishment of male marital authority, ${ }^{63}$ they also recognised the risks of proliferating childhood statelessness through GDNL. ${ }^{64}$ International jurists at the Hague Conference were in fact more open to preventing statelessness than they were to engaging with feminist principles of equality, wanting to find solutions to statelessness with 'as little disruption as possible to male headship of marriage' ${ }^{65}$

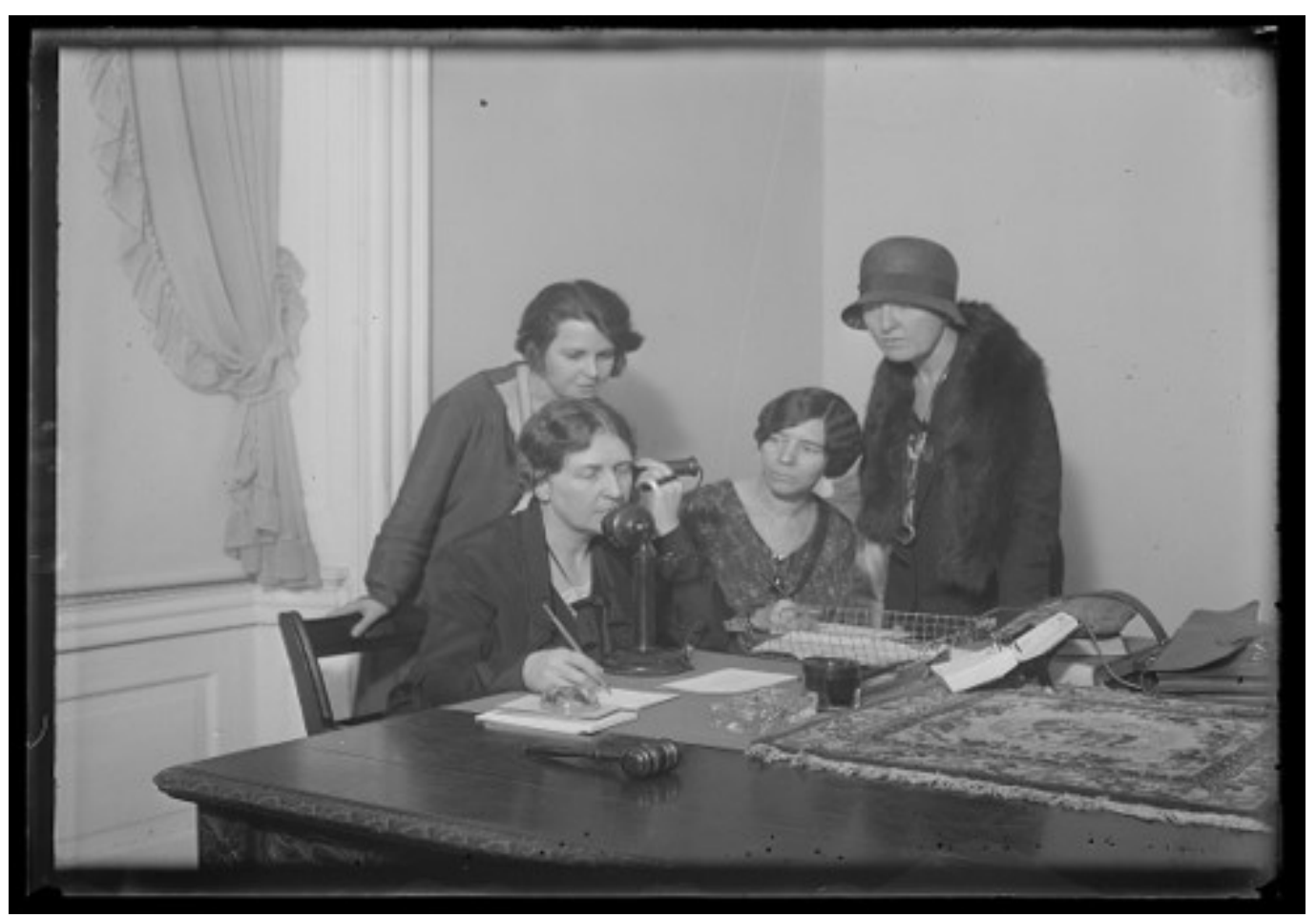

Image 2: From Washington, National Women's Party members telephone their colleague, Doris

Stevens, in The Hague to ascertain whether the World Code being drawn up on nationality laws will be based on sex discrimination. 66

Manley O Hudson's role in the feminist history of statelessness is once again noteworthy. It appears for Hudson that the Hague Convention was a significant achievement, if not least because it had been the only codification convention

62 Irving (n 7) 173.

63 DuBois (n 7) 207.

64 In 1934, Blanch Crozier noted:

There are already thirteen countries in the world in which men and women transmit nationality to children upon the same terms (Argentina, Chile, Colombia, Dominican Republic, Ecuador, Nicaragua, Panama, Paraguay, Peru, Soviet Russia, Turkey, Uruguay, Venezuela), and no greater difficulties have been encountered than in countries where the father alone has the right to transmit nationality.

Crozier (n 7) 152.

65 DuBois (n 7) 207.

66 'Media', Picryl (Web Page) <https://picryl.com/media/feminists-telephone-the-hague-todetermine-their-status-in-proposed-world-code>. 
produced by the Hague Conference. Yet, to his disappointment, the US cast the only dissenting vote against it, the other 40 countries voting in favour. Recalling these events three years after the fact, a frustrated Hudson wrote, 'a persistent attack has been made on the Convention ... in so far as it affects the nationality of women'. ${ }^{67}$ Hudson believed that opposition to the Hague Convention by profeminist campaigners was based on misinterpretations of the effects of arts 8-11.68 His main accusation was aimed at James Brown Scott, president of the American Institute of Law and an ally to the feminist cause. ${ }^{69}$ Quoted in an article in the US Good Housekeeping magazine in 1931, Scott said: 'Articles 8, 9, 10, and 11, setting forth a man's view of the nationality of married women, are, as would be expected, based upon the principle of masculine superiority'. ${ }^{70}$ The US dissenting vote was still a cause to rejoice for US feminists at the time. ${ }^{71}$ Alva Belmont of the US National Women's Party scoffed at the European signatories:

These men have lost their slaves. They have lost their serfs. They have lost their dominion over the working class. They still think they can dominate women. It terrifies them to think that in the future women mean to govern themselves. ${ }^{72}$

Hudson, on the other hand, believed that the US government had meekly succumbed to the feminist campaigners:

[T] he Government of the United States is more intent upon mollifying a section of its own public opinion than upon grappling with the very real problems which exist today and which the convention is designed to solve. Apparently, the attitude of the United States is one of complete helplessness in the face of these problems. ${ }^{73}$

Hudson acknowledged that articles in the Hague Convention were not based upon the principle of equality between men and women. But he simply dismissed the idea that equality could serve as a guide for international legislation that sought to resolve conflicts that arose from legal differences. ${ }^{74}$

The work of feminists was not over. In succeeding years, governments were either frustrated or bemused by the continuing campaigns for the eradication of GDNL when statelessness, in their view, had been addressed by the Hague Convention. ${ }^{75}$ During the League of Nations Council Meeting in January 1931, women from all over the world sent campaigning telegrams to Council members. British Foreign Minister Arthur Henderson, president of the Council at the time, received 210 telegrams in less than 48 hours, 150 of these from England. ${ }^{76}$ As a result of the telegram campaign, and on the initiative of the representatives of Guatemala, Peru and Venezuela, the Council agreed to place the nationality of married women on the Assembly agenda. ${ }^{77}$ Moreover, it invited eight transnational women's organisations to form a committee within the Council of

67 Manley O Hudson, 'The Hague Convention of 1930 and the Nationality of Women' (1933) 27(1) American Journal of International Law 117, 117.

68 ibid 121.

69 Bredbenner (n 1) 204-5.

70 O H P Belmont, ‘Are Women Really Citizens?' (September 1931) Good Housekeeping 99, 132.

71 Bredbenner (n 1) 213.

72 ibid 215.

73 Hudson (n 67) 122.

74 ibid 121.

75 Irving (n 7) 240.

76 Miller (n 6) 227.

77 Hudson (n 67) 118. 
the League of Nations. ${ }^{78}$ The committee's proposals would be presented to the Twelfth Assembly in 1931.79

The new committee, entitled the Women's Consultative Committee on Nationality (the 'Committee') brought forward proposals opposing the Hague Convention because 'it differentiates between men and women as regards nationality'. ${ }^{80}$ Instead, the Committee insisted that each state party should agree that 'there shall be no distinction based on sex in their law and practice relating to nationality'. ${ }^{81}$ In counterpoint to the Hague Convention, the Committee emphasised how women were 'deeply concerned to see that articles predicated on the theory of women's subordination have been included in an international agreement'. ${ }^{82}$ They maintained that recognising the 'old idea' of subordination in practice was to 'refuse [women] adult status'. 83

\section{F The Convention on the Nationality of Women 1933}

One of the major achievements of the 1920-30s period was that, following years of advocacy and research by the Inter-American Commission of Women, an equal-nationality treaty was on the agenda of the 1933 Pan American Union Conference. Out of this Conference came the adoption of the world's first international convention relating to women's nationality rights, or to women's rights of any kind, the Convention on the Nationality of Women. Article 1 specified that signatories agreed that ' $[\mathrm{t}]$ here shall be no distinction based on sex as regards nationality, in their legislation or in their practice'. ${ }^{84}$

\section{G The Ferocity of the Feminist Cause}

It will be necessary in due course to examine the gradual disintegration of the international-level citizenship campaigns, but in order to illustrate the full extent of the campaigners' influence throughout the 1920s and '30s, it is instructive to home in on a specific national case. Irish historian Mary Daly has examined the dynamics between the newly emerging Irish Free State and the citizenship equality campaigners. ${ }^{85}$ This is a case that neatly demonstrates the integrated role of international pressure, religious influence and political will in overcoming GDNL, factors that may impact on campaigning work today.

In 1926, when the Irish Free State was only four years old and still a British Dominion, the Irish Secretary of State, Kevin O'Higgins, speaking at an Imperial Conference for Dominions of the Empire of London (the 'Imperial Conference'), dismissed Ireland's need to eradicate GDNL. O'Higgins reasoned that 'there is not in the Irish Free State the same pressure from feminist movements, which ... exists in Great Britain'. ${ }^{86}$ At the Imperial Conference, only South Africa and Ireland

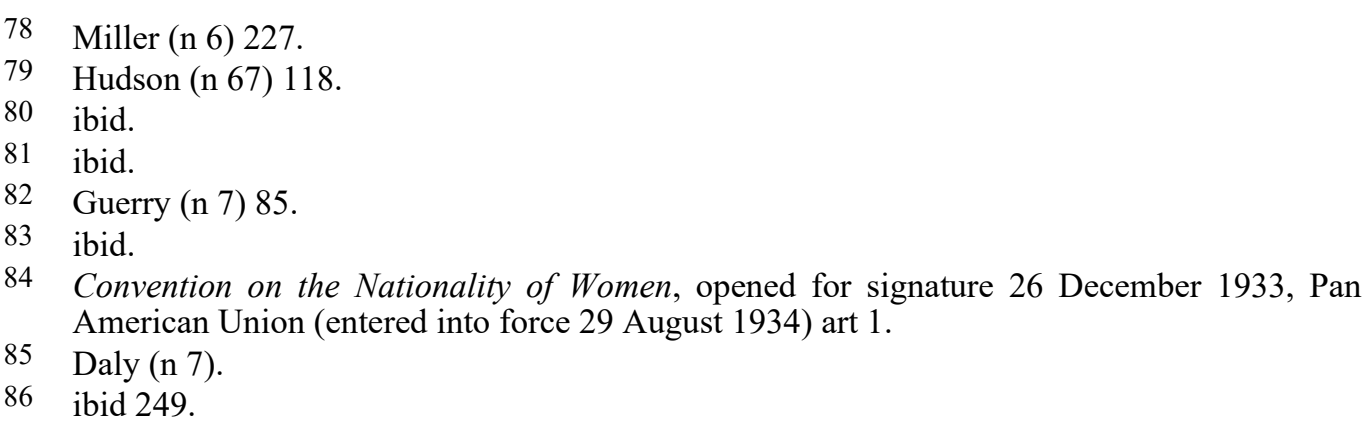


opposed altering a law regarding the nationality of married women. ${ }^{87}$ However, O'Higgins suggested that Britain was not in agreement either about altering the law, and claimed that Britain was using South Africa and Ireland as scapegoats for their inaction on women's equality. ${ }^{8} \mathrm{He}$ argued that if the position of South Africa and Ireland became known then they would be 'delivered into the hands of the feminist organisations of the Commonwealth of Nations as a whole burnt offering $\ldots$ and would be represented as the enemies of mankind' ${ }^{89}$ O'Higgins wanted the draft report to protect the anonymity of the delegates, and, according to Mary Daly it appears that he had his way. ${ }^{90}$

Ireland was at the time a burgeoning Catholic Church-dominated state. At the Imperial Conference, O'Higgins claimed that separate nationalities for husband and wife were 'not quite in accord with the concept of a Christian marriage'. ${ }^{91}$ This was echoed at the international level by a number of Catholic associations fiercely opposed to equal nationality rights between men and women. ${ }^{92}$ Such Catholic organisations argued that the unity of the family must be protected through a commonly shared nationality by mother, father and children. A memorandum by the International Union of Catholic Women's Associations stated that the aim of any new laws on nationality should not be the emancipation of women..$^{93}$ On the other hand, there were Catholic organisations that maintained that equal nationality rights between men and women had in no way affected family unity. These organisations cited Argentina, Chile, Paraguay and Uruguay as Catholic countries where no distinctions on the basis of sex were made in nationality laws. ${ }^{94}$ Furthermore, two Catholic petitions, one signed by men, one by women, were sent to the League of Nations in 1932, in support of equal nationality laws. The petitions received 8,000 signatures from 23 countries. ${ }^{95}$

In Ireland, shifting political landscapes and leaders would eventually change the state's position on GDNL. Following a general election in Ireland in 1932, O'Higgins's party Cumann na nGaedheal (The Irish People's Party) was defeated by Fianna Fáil (The Soldiers of Destiny). Éamon de Valera became Prime Minister and, in the same year, became acting president of the League of Nations. De Valera, who was born in New York to an Irish mother and a Cuban father, favoured gender-neutral laws, but only up to a point, as will be seen. By 1935, under Fianna Fáil's rule, some progress was made and Irish nationality by descent was permitted, in certain circumstances, through either parent:

[A] person born before 6 December 1922 [the date of the adoption of the Constitution of the Irish Free State, the first Irish constitution] outside the state could claim Irish citizenship ... if one parent had been born in Ireland. But for those born outside the state after that date, citizenship could be transmitted only through the father. ${ }^{96}$

\footnotetext{
87 ibid 250.

88 ibid.

89 ibid 251.

90 ibid 251 n 23.

91 ibid 249.

92 ibid 254.

93 ibid.

94 Guerry (n 7) 89.

95 ibid.

96 Daly (n 7) 260.
} 
De Valera's comments, in a parliamentary debate leading up to the Irish Nationality and Citizenship Act 1935 (the '1935 Citizenship Act'), reveal how global trends were at that time deciding the limits of his willingness to eradicate GDNL:

Why should we increase the conflict and the confusion by having descent through either parent? As no hardship that I could see would result from it, I - not without regret - set aside the principle of descent through either parent and restricted myself in the Bill to the principle of descent through the father. If the principle of descent through the mother had been well established elsewhere, I should not object. I did not want to have descent through the father simply because he was the father but because that principle is almost universally established, whereas the other principle would be novel and strange. I should rather have descent, in present circumstances, through the mother alone than to have it through both parents because there would be less confusion but, in this case, we would be establishing a new principle and we would be leading in the direction of increased confusion ... 97

De Valera, despite his genealogy, was not here implying a preference for matrilineal transference of nationality over patrilineal transference. ${ }^{98} \mathrm{He}$ was merely making the rhetorical point that if he were forced to choose between matrilineal transference and parental (either parent) transference he would choose the former, simply to avoid the complications of the latter. The opposition party, Cumann na nGaedheal - which had spent the previous ten years in office without granting women equal citizenship rights — objected 'strongly' to de Valera's proposal that citizenship would be transmissible through fathers only. ${ }^{99}$ James Michael Burke, a lawyer and member of the opposition, expected that in 'these modern times' and 'days of enlightenment' women should be granted equal rights with men. ${ }^{100}$ Burke also brought up a historical argument, stating that:

[I]n very many countries in early times, descent was traced not through the father, but through the mother. That may come as a surprise to some members of the House, but if they will look at the Greek word for brother - adelphos - they will see that it suggests that it was through the mother and not through the father that succession came. ${ }^{101}$

Burke's argument made no impact on the final provisions of the 1935 Citizenship Act, rather the global status quo prevailed.

On the contrary, in the international arena, in his role as acting president of the League of Nations, de Valera appeared committed to the cause of women's equality. A resolution proposed in 1932 by a Belgian delegate, and supported by the Irish government, was to replace all references to woman/wife in arts 8-11 of the Hague Convention with the gender-neutral 'person'. 102 On 31 October 1932, Alice Paul, who represented the Inter-American Commission of Women at Geneva, thanked de Valera for his 'exceedingly generous support during our campaign'. 103

Dáil Éireann Debates (Ireland) 19 December 1934, Vol 54(10) ('Dáil Éireann Debates').

Pace Daly (n 7) 261.

99 Dáil Éireann Debates (n 97).

100 ibid.

101 ibid

102 Daly (n 7) 256-57.

103 ibid 257. 
Transmission of citizenship by either parent was eventually legalised in Ireland in the 1956 revised Irish Nationality and Citizenship Act. ${ }^{104}$ In the debates leading up to this Act, Ireland's Department of Justice was determined to maintain conferral of citizenship by descent through a patrilineal line only, but de Valera successfully opposed the move, with the result that Irish nationality law became more progressive than both the 1935 Citizenship Act and the citizenship laws of Britain, the former coloniser. 105

\section{$\mathrm{H} \quad$ The End of the Campaigns?}

The question as to what extent the citizenship equality campaigns of the 1920-30s came to an end at the outbreak of the Second World War in 1939 has no definitive answer. Most of the scholarship on the equal citizenship campaigns of the first half of the twentieth century focuses on the interwar period, and - perhaps at the height of those campaigns - the Hague Convention in 1930. Miller writes that, thanks to persistent demands to advance the status of women, the League of Nations Assembly in 1937 finally approved a plan for a comprehensive and scientific inquiry into the legal status of women throughout the world. 106 However, the work of the inquiry committee that was set up appears to have been brought to a halt by the beginning of the Second World War. ${ }^{107}$ Nonetheless, the work of feminists in the 1930s would bear further fruit in the creation of the UN Status of Women Commission in 1946. ${ }^{108}$ Successive international treaties and conventions would continue to crop up until the Convention on the Elimination of All Forms of Discrimination against Women was drafted in $1981 .{ }^{109}$ And with it, at last, came a full and comprehensive convention requiring equal nationality rights for women.

\section{Part 2: Decentring Statelessness History - A Discussion}

\section{A Introduction}

An analysis of the key events and characters from the early 1900s, described in part one of this article, can be a source of inspiration and lessons for today's campaigns against GDNL. To draw out such lessons it is useful to reflect on the foresight of equality campaigners on statelessness issues, and on the nature of the opposition they faced, and also to question the role of race in the history of GDNL.

104 Irish Nationality and Citizenship Act 1956 (Ireland) ss 6(1)-(2).

(1) Every person born in Ireland is an Irish citizen from birth.

(2) Every person is an Irish citizen if his father or mother was an Irish citizen at the time of that person's birth or becomes an Irish citizen under subsection (1) or would be an Irish citizen under that subsection if alive at the passing of this Act.

105 Daly (n 7) 262.

106 Miller (n 6) 237.

107 ibid 238.

108 ibid 237.

109 ibid 239; Convention on the Elimination of All Forms of Discrimination against Women, opened for signature 18 December 1979, 1249 UNTS 13 (entered into force 3 September 1981). 


\section{B Feminist Ferocity and Foresight}

From as early as 1905, feminist foresight recognised the perils of statelessness, and the word itself was very much part of feminist activist's vernacular during that period. In 1926, Bertha Lutz, prominent Brazilian suffragette and zoologist, wrote that one of the results of conflicts in nationality laws between nations was 'total loss of nationality rights in any country, with the attendant loss of legal protection and citizenship'. ${ }^{110}$ In Lutz's piece, persons without nationality are referred to by the German word, heimatlos (homelandless). ${ }^{111}$ In 1925, Chrystal Macmillan explained how statelessness occurs from the restriction of women's independent right to a nationality, and spoke of the need to cultivate international action and agreement between states 'in order to prevent the hardships which arise from statelessness or from conflicts of law'. ${ }^{112}$ Although it is virtually a rite of passage in statelessness academia to cite Hannah Arendt's 1966 reflection on citizenship as 'the right to have rights', 113 this same sentiment was in the hearts of feminists in the 1920s, with Macmillan pointing out that 'nationality is the most fundamental of political rights'. ${ }^{114}$ Similarly, British president of the International Woman Suffrage Alliance, Margery Corbett Ashby, described nationality as the 'most important of all personal privileges'. ${ }^{115}$ In the history of statelessness, it is vital not only to acknowledge the vigorous activism by feminist campaigners, but also their scholarship on the issue. Half a century before a legal definition even existed, statelessness was seen by feminist scholars and organisations as a major issue facing women.

At the core of the early campaigners' demands was a whole-hearted commitment to equality, a commitment that can be looked at in two ways. Firstly, it could be argued that feminists' battle was against the use of citizenship laws as an instrument of subordination and exclusion. This struggle foresaw issues that arise from exclusionary citizenship laws today, and not just discrimination against women. De Gouges's feminist manifesto, in eighteenth century France, was a recognition of how the legal citizenship status coming into existence was intrinsically founded on the exclusion of others. Among the 'motley assortment of civic outsiders' defined as passive citizens, were the stable women, born into and remaining in the role of the citizen's 'Other'. ${ }^{116}$ This is a practice of defining a citizen in opposition to what it is not and continues to this day. Patriarchal agendas attempt to maintain power and dominance by excluding certain 'Others' from state membership. ${ }^{117}$ For example, in the context of statelessness among the Rohingya community, and the potential statelessness of Muslim Indians of Bengali heritage

110 Bertha Lutz, 'Nationality of Married Women in the American Republics' (1926) 60(4) Bulletin of the Pan American Union 392, 396.

111 ibid 399.

112 Macmillan (n 7) 152.

113 Hannah Arendt, The Origins of Totalitarianism (Schocken Books 1951) 296.

114 Chrystal Macmillan, The Nationality of Married Women (Nationality of Married Women Pass the Bill Committee 1931) 7.

115 Guerry (n 7) 81.

116 Smart (n 22) 134.

117 Deirdre Brennan, 'Statelessness and the Feminist Toolbox: Another Man-Made Problem with a Feminist Solution?' (2019) 24(2) Tilburg Law Review 170, 174. 
in Assam, citizens are being defined in opposition to a certain ethnicity or religious belief. 118

Secondly, interpreting the early campaigners' steadfast commitment to equality can be a source of inspiration for today's GDNL campaigns. Nationality laws that prevent a woman from passing on her nationality to her child arguably receive more attention by statelessness actors or international organisations today than the laws that discriminate against a woman in her right to acquire, change or retain her nationality. ${ }^{119}$ Understandably, statelessness is more of an immediate risk in countries where children cannot acquire their mother's nationality, and the necessity for campaigns on the issue is unquestionable. Also, given the fact that the Convention on the Rights of the Child is the world's most widely ratified human rights treaty, ${ }^{120}$ canvassing against this form of GDNL may be easier. However, 1930s campaigners did not give up their fight when safeguards against statelessness were drawn up, but instead, stuck to the principle of equality. This raises the question of whether GDNL campaigns today should also place their emphasis on women's equality as the overarching need for law reform. In fighting, first and foremost, for equal nationality laws between men and women, it is arguable that campaigns to eradicate GDNL 100 years ago were less conservative in their demands than some of the campaigns today. Furthermore, it is worth considering if the grouping of 'women and children' in today's campaigns against GDNL is problematic. ${ }^{121}$ Does grouping women's and children's rights together reproduce the infantilisation of women? And, to use the phrasing of the 1931 Women's Consultative Committee on Nationality, does this focus 'refuse [women] adult status' in their own right? ${ }^{122}$

One of the key lessons to take from the early campaigners is the value of collaboration. Campaigners in the early 1900s overcame financial, logistical and linguistic barriers to meet at The Hague in 1930, launch international campaigns such as the telegram campaign in 1931, and to collate an 84-country report on nationality laws. This is to say nothing of the equality treaties and conventions that the campaigners drew up and lobbied for in the face of relentless opposition. Collaboration in the form of international support also reached the activists:

Distinguished editors, men and women of letters, jurists, and feminists from all over the world have sent encouragement, congratulations and approval. The responses range from India to Greece, and from Canada to the Argentine. ${ }^{123}$

118 See, eg, Nyi Nyi Kyaw, 'Unpacking the Presumed Statelessness of Rohingyas' (2017) 15(3) Journal of Immigrant and Refugee Studies 269, 269-86; Bilal Kuchay, 'What You Should Know about India's “Anti-Muslim” Citizenship Law', Al Jazeera (online, 16 December 2019) $<$ https:/www.aljazeera.com/news/2019/12/india-anti-muslim-citizenship-bill191209095557419>.

119 Cf Global Action Plan to End Statelessness: 2014-2024 (Report, UNHCR 2014) 15.

120 The United Nations Convention on the Rights of the Child (Information Booklet, Children's Rights Alliance June 2010) 1; 'UN Lauds Somalia as Country Ratifies Landmark Children's Rights Treaty', UN News (Web Page, 20 January 2015) $<$ https://news.un.org/en/story/2015/01/488692-un-lauds-somalia-country-ratifies-landmarkchildrens-rightstreaty\#: :text=The $\% 20 \mathrm{CRC} \% 20$ was $\% 20$ adopted $\% 20$ by,human $\% 20$ rights $\% 20$ treaty $\% 20 \mathrm{in}$ $\% 20$ history>.

121 Cf Cynthia Enloe, “"Womenandchildren”: Propaganda Tools of Patriarchy' in Greg Bates (ed), Mobilizing Democracy: Changing the US Role in the Middle East (Common Courage Press 1991) 29-32; Institute on Statelessness and Inclusion, World Conference on Statelessness (Report, 2019) 11-15.

122 Guerry (n 7) 85

123 Lee (n 7) 228. 
Today, with profound improvements in telecommunications, and far more financial and logistical resources, it is realistic for international organisations to aim to facilitate frequent and consistent collaboration between activists in the 50 countries where GDNL persists. In honouring the work of international activists a century ago, and to foster the work of national activists today, activists from each country could be brought together on an annual basis to develop their ideas for global action against GDNL. ${ }^{124}$ Furthermore, not only is collaboration needed across countries affected by GDNL, but wider attention to the issue - sometimes lacking among feminist allies in other areas of scholarship and activism - is sorely required. Drawing on campaign tactics by, and receiving support from, prolific global feminist activist groups, such as the reproductive rights movements, could help widen awareness on the issue. ${ }^{125}$

\section{Overcoming Opposition}

Opposition to citizenship equality is deeply rooted in history: Napoleon's establishment of nationality through male lineage shows us as much. This eighteenth century law was based on the notion that loyalty is extended only through a male bloodline. The Napoleonic sentiment is reflected today in twentyfirst century Nepal. Grossman and Dennis argue that resistance to allowing women to pass on their nationality in Nepal is embedded in "the real and potential coupling of Nepali women and Indian men whose children would further "Indianize" Nepal'. ${ }^{126}$ The assumption here is that if a child has an Indian father - even if that child grows up in Nepal with a Nepali mother - the child's loyalty will always be only to that of his or her father's country, India. Eradicating GDNL in Nepal today is thus a battle against a very old, deep-rooted, paranoia.

The history of GDNL campaigns also reveals how one of the equality campaigners' earliest opponents is, today, ironically held in high esteem in statelessness history. As noted, Manley O Hudson's work at the International Law Commission led to the definition of a stateless person in the 1954 Convention Relating to the Status of Stateless Persons (the '1954 Statelessness Convention'). However flawed the definition remains today, ${ }^{127}$ Hudson's position in statelessness history could, at face value, be counted as honourable. Yet, we have seen in his refusal to advocate for women's equal nationality rights, especially in the US, that Hudson's track record appears less noble. It raises the question as to

124 The first ever global meeting of the Global Campaign for Equal Nationality Rights took place in Istanbul in 2019. Civil society leaders from Africa, the Caribbean, the Middle East, South Asia and Southeast Asia were in attendance: see 'A Call for Urgent Action to End Gender Discrimination in Nationality Laws: Governments Contradict Their Pledges to Gender Equality', Global Campaign for Equal Nationality Rights (Web Page, 2 May 2019) $<$ https://equalnationalityrights.org/news/96-end-gender-discrimination-in-nationality-globalstatement-2019>.

125 See, eg, Nosheen Iqbal, 'Women around the World March against Austerity and Violence', The Guardian (online, 20 January $<$ https://www.theguardian.com/world/2019/jan/19/womens-march-london-against-austerityprotesters-worldwide>; Ciara Kenny, 'March for Choice Goes Global with Protests Planned for 25 Cities', The Irish Times (online, 19 September 2016) $<$ https://www.irishtimes.com/march-for-choice-goes-global-with-protests-planned-for-25cities-1.2796837>.

126 Barbara Grossman-Thompson and Dannah Dennis, 'Citizenship in the Name of the Mother: Nationalism, Social Exclusion, and Gender in Contemporary Nepal' (2017) 25(4) Positions 795, 796.

127 Cf Michelle Foster and Hélène Lambert, International Refugee Law and the Protection of Stateless Persons (Oxford University Press 2019) 107. 
whether Hudson's personal frustrations with feminist campaigners led to the exclusion of any reference to gender discrimination in both the 1954 Statelessness Convention and the 1961 Convention on the Reduction of Statelessness. ${ }^{128}$

The case of Ireland enabled us to look at how opposition to citizenship equality can hang in the balance between geopolitics, international pressure (or shame) and local dominant-religious mores, and consequently how women's rights can be used as a political football. In the 1920s, Ireland feared being known by international feminist movements as opposing equal citizenship. And so while Ireland claimed not to be under pressure from local feminist groups to ameliorate the matter, the ruling party in 1926 dismissed the issue, reckoning that the Irish 'are a conservative people'. ${ }^{129}$ In 1934, the same political party, no longer in power, challenged the then ruling party's failure to eradicate GDNL. Examples of this kind of rhetorical gamesmanship on the part of governments who superficially support women's equality, but never reflect such sentiments in practice, are frustrating to campaigners down to the present day. Thus, while Ireland's Prime Minister, Éamon de Valera, was seen by some in Geneva as a leader against GDNL, he did not display the courage at home to deviate from global trends and fully eradicate GDNL.

Furthermore, the fact that decades later, in the 1950s, Irish women were granted equal citizenship rights ahead of Ireland's former colonisers, shows how fiercely Ireland wanted its citizenship laws to differ from Britain's. ${ }^{130}$ In postcolonial countries where GDNL prevails as a result of inherited laws, it may be worth playing on decolonial sentiment, emphasising that the eradication of colonial influence is today well overdue.

\section{A Whitewashed and a Forgotten History}

In a fascinating twist of fate, the first Global Forum on Statelessness in 2014 was held at the Peace Palace in The Hague, the same historical grounds as in the 1930 conflict. The Global Forum was said to have marked the $60^{\text {th }}$ anniversary of the 1954 Statelessness Convention. ${ }^{131}$ But when feminist history is included, the Forum in fact marked the $84^{\text {th }}$ anniversary of the infamous Palace protest lock-out. These two events stand in sharp contrast to one another. With almost a century between them, GDNL as a cause went from being locked out of the Palace gates, to being openly addressed within them.

In contemporary statelessness literature, the gap in general awareness of the early campaigns, may be due to the fact that several authors of the 1930s campaigns are historians, and their works were simply missed. Indeed, authors who work on the early campaigns for citizenship equality note how relatively unexplored this dimension of twentieth century feminist history is. ${ }^{132}$ Unfortunately, in addition to the lack of attention paid to earlier campaigns, most historians do not refer to the ongoing existence of GDNL at the time of their

\footnotetext{
128 Brennan (n 117) 175.

129 Daly (n 7) 250

130 ibid 245.

131 Lindsey N Kingston, 'Conceptualizing Statelessness as a Human Rights Challenge: Framing, Visual Representation, and (Partial) Issue Emergence' (2019) 11(1) Journal of Human Rights Practice 52, 57.

132 DuBois (n 7) 204; Bredbenner (n 1) 2; Irving (n 7) vii; Amorosa (n 7) 416.
} 
publications, with the exception of one or two accounts. ${ }^{133}$ GDNL as a cause is therefore forgotten on multiple levels.

In remembering and honouring the early 1900s campaigns, it is nonetheless important to maintain a critical perspective of their campaigns and the histories written about them. These have centred on white Western heroines. As noted earlier, this article has not dealt with the likely suppression of the voices of women of colour in the earlier citizenship equality campaigns, nor has it covered the ways in which nationality and immigration laws affect(ed) women of colour in Western countries. ${ }^{134}$ The role race and geographical inequality play in the continued neglect of GDNL is a subject that requires another study. By way of illustration, the 50 countries that retain GDNL today are, with the exception of Monaco, nonWestern. ${ }^{135}$ This is a worrying reflection of perhaps how, once women in the West were granted full nationality rights over the course of the twentieth century, nonWestern countries were forgotten. Reflecting on the vibrancy and creativity of the early 1900s campaigns, it is disappointing to think that such urgency was not extended to, or maintained for, countries in their postcolonial independence era.

\section{CONCLUSION}

As is so often said about change-makers from the past, we stand on the shoulders of giants, and the seminal work of early twentieth century campaigners still provide key lessons and inspiration for the ongoing campaigns of today. The feeble attitude of 'this is how it has always been done' that surfaced in the early Irish debates on citizenship is still to be heard almost 100 years later, and remains a huge hurdle to equality in the countries that retain GDNL. Women's rights can be tossed about as a rhetorical device, or political football, without any practical commitment from politicians in power to reform the law. However, if there is any lesson to be learned from the history of the citizenship equality campaigns it is that persistence pays. Rights advocacy can be a long game and activists may not see the fruit of their work in their own lifetime, but no committed effort is ever wasted. If the historical citizenship campaigns are no longer overlooked, the persistence and dynamism of those involved will serve as an ongoing reminder of the importance of financially supporting activists to work, in a united front, toward the full eradication of GDNL.

During the interwar years, feminist campaigners were filled with energy to eradicate GDNL. At the Hague Conference in 1930, campaigners even announced that they would remain committed to the cause for another 25 years. This makes one wonder how disappointed those campaigners would be if they witnessed the persistence of GDNL almost a century later. On the other hand, it is possible to question why the energy of the interwar feminists was not carried on for the other countries that upheld GDNL in the decades that followed. One could ask too why

133 In her 2001 piece on GDNL in international law, Knop notes that challenges to GDNL were 'currently before the courts in Bangladesh, Nepal, and Pakistan': Knop (n 8) 91. Cherif, who provides an overview of the 1930s campaigns, analyses why GDNL was eradicated in Morocco in 2007 but not in Jordan. However, Cherif's conclusions rely on unsubstantiated justifications and makes very problematic generalisations of those countries: see Cherif (n 7) 85.

134 For an explanation of how campaigning for women's equal nationality rights in Britain was conducted in racist terms: see Women, Immigration and Nationality Group, Worlds Apart: Women under Immigration and Nationality Law (Pluto Press 1985).

135 The Problem (n 2). 
we are left with a situation where all but one of the countries with GDNL are nonWestern, where global public awareness on the issue is lacking, and where any transnational feminist commitment to the cause is a diluted version of that of the 1930s. The bottom line is that the campaigns from the early 1900s highlight the long-overdue nationality rights of all women that are still in need of attention. At a time when the centenary of suffrage is being celebrated around the world, can the campaign for women's equal nationality rights, an early sister to those suffrage campaigns, receive the awareness it needs to be finally fulfilled? 